\title{
HARLOW V. FITZGERALD: THE LOWER COURTS IMPLEMENT THE NEW STANDARD FOR QUALIFIED IMMUNITY UNDER SEGTION 1983
}

\section{INTRODUCTION}

Section $1983,{ }^{1}$ enacted in 1871 as part of the Ku Klux Act, ${ }^{2}$ provides a right of action for parties deprived of their constitutional or federal statutory rights ${ }^{3}$ by actions taken "under color of" state law." Section 1983 thus holds public officials who violate an individual's rights under the fourteenth amendment liable for that violation.

A suit brought under section 1983 may have any of three substantive effects. ${ }^{5}$ One intended effect of the statute is to deter public officials from violating constitutional rights; another is to provide compensation to injured citizens when such deterrence has failed. ${ }^{\bullet}$ In addition, the

142 U.S.C. $\$ 1983$ (Supp. V 1981) provides:

Every person who, under color of any statute, ordinance, regulation, custom, or usage, of any State or Territory or the District of Columbia, subjects, or causes to be subjected, any citizen of the United States or other person within the jurisdiction thereof to the deprivation of any rights, privileges, or immunities secured by the Constitution and laws, shall be liable to the party injured in an action at law, suit in equity, or other proper proceeding for redress. For the purposes of this section, any Act of Congress applicable exclusively to the District of Columbia shall be considered to be a statute of the District of Columbia.

2 The Ku Klux Act, ch. 22, § 1, 17 Stat. 13 (1871) (current version at 42 U.S.C. $\S 1983$ (Supp. V 1981)). The Act was passed, along with other legislation, in reaction to violence fostered by the Ku Klux Klan. Although its most immediate concern was thus focused upon activities such as those of the Klan, the Act was intended to serve as a remedy for any violation of rights secured by the fourteenth amendment. See Monroe v. Pape, 365 U.S. 167, 172-83 (1961); see also S. NAHMOD, GiviL RIGHTS \& GiviL LIBERTIES LITIGATION 3-4 (1979).

s While there is some debate about what laws are included under section 1983's right of action, the Supreme Court has construed the "and laws" phrase of section 1983 to mean that the statute "broadly encompasses violations of federal statutory as well as constitutional law." Maine v. Thiboutot, 448 U.S. 1, 4 (1980).

"The "under color of" requirement is fulfilled by actions authorized by state laws, by the uneven application of state laws, and by abuses of power "made possible only because the wrongdoer is clothed with the authority of state law." Monroe v. Pape, 365 U.S. 167, 184 (1961) (quoting United States v. Classic, 313 U.S. 299, 326 (1941) (Stone, J.)).

s Section 1983 does not itself create any substantive rights; rather, it creates a right of action to vindicate substantive rights guaranteed by the Constitution or federal statute. See, e.g., Baker v. McCollan, 443 U.S: 137, 144 n.3 (1979).

- See Carey v. Piphus, 435 U.S. 247, 253-57 (1978) (section 1983 provides damages to compensate persons for injuries caused by deprivations of constitutional rights; the statute-and damages awards-also embrace the purpose of deterring deprivations of constitutional rights); see also S. NAHMOD, supra note 2 (section 1983 is designed to 
statute has had the very significant effect-probably unintended by the drafters of the act-of serving as a mechanism for the expansion and development of federal constitutional rights. ${ }^{7}$

The substantive significance of the statute is magnified by the sheer number of suits that have been brought under section 1983 since the landmark decision of Monroe v. Pape. ${ }^{8}$ Judges and commentators

prevent violations of the fourteenth amendment and certain federal rights and to compensate persons whose rights are nonetheless violated). But see Schuck, Suing Our Servants: The Court, Congress, and the Liability of Public Officials for Damages, 1980 SuP. CT. REv. 281, 339-45 (suggesting that section 1983 does not effectively accomplish the goals of victim compensation and deterrence).

7 See Whitman, Constitutional Torts, 79 MICH. L. Rev. 5, 15, $20-21$ (1980).

365 U.S. 167 (1961).

In a series of cases near the turn of the century, the Supreme Court held that the fourteenth amendment applied only to state action and that state action did not include behavior by a state official that was illegal under state law. Since the fourteenth amendment was viewed as not applying to ultra vires behavior by state officials, the "privileges and immunities" clause of section 1983 was considered inapplicable to such illegal actions. See Developments in the Law: Section 1983 and Federalism, 90 Harv. L. REv. 1133, 1156-61 (1977) [hereinafter cited as Section 1983 and Federalism]. Under this narrow interpretation, section 1983 applied only to official action made "pursuant to an unconstitutional state statute or local ordinance." Id. at 1168. The Court's policy of not incorporating much of the Bill of Rights into the fourteenth amendment also restricted the scope of potential violations to which section 1983 applied. See S. NAHMOD, supra note 2, at 35; accord Section 1983 and Federalism, supra, at 1169. This restrictive interpretation of section 1983 so discouraged potential plaintiffs that only 21 cases were decided under the statute in the first 50 years after its enactment. See Maine v. Thiboutout, 448 U.S. 1, 27 (1980) (Powell, J., dissenting).

In Monroe the Court rejected the narrow interpretation of section 1983 by reinterpreting the "under color of [state] law" requirement. This reinterpretation played a significant role in the post-Monroe flood of section 1983 litigation.

Monroe held that section 1983 authorized a right of action not only in situations where the constitutional or statutory deprivation was authorized by state law or by a discriminatory application of state law, but also in situations where the violation was made possible only because the public official was vested with the authority of state law, even where the particular actions taken also violated state law. See Monroe, 365 U.S. at 184. The fact that state law also provided a remedy against the particular action alleged was not a barrier to suit in federal court under section 1983, and there was no requirement that the petitioner have first exhausted that state law remedy since the federal remedy "is supplementary to the state remedy." Id. at 183 . In addition the range of possible violations to which section 1983 applied expanded as the Court incorporated more of the Bill of Rights into the fourteenth amendment. See Section 1983 and Federalism, supra, at 1169; see also S. NAHMOD, supra note 2, at 1168-70.

These factors combined to spark a tremendous increase in the number of section 1983 actions filed in the years after Monroe. "Between 1961 and 1979, the number of federal filings under $\S 1983$ (excluding suits by prisoners) increased from 296 to 13,168. Civil rights petitions by state prisoners increased from 218 cases in 1966, to 11,195 in 1979. In 1976, almost one out of every three 'private' federal question suits filed in the federal courts was a civil rights action against a state or local official." Whitman, supra note 7, at 6; see Note, Federalism, Section 1983 and State Law Remedies: Curtailing the Federal Civil Rights Docket by Restricting the Underlying Right, 43 U. PITT. L. REv. 1035, 1045 (1982); see also Aldisert, Judicial Expression of Federal Jurisdiction: A Federal Judge's Thoughts on Section 1983, Comity E' Federal Caseload, 1973 LAw \& SOC. ORD. 557, 563 (calling post-Monroe filings a "deluge" 
alike have reacted to the tremendous increase in section 1983 litigation with serious concern. They have pointed both to the increased vulnerability of public officials to liability for damages ${ }^{9}$ and to the substantial pressure on the federal judiciary from the increased caseload ${ }^{10}$ as reasons for restricting the sweep of section 1983.

Such concerns have moved courts to re-examine methods for limiting the impact of section 1983 upon public officials. In particular there is renewed interest in the traditional immunity defenses that officials may use to shield themselves from liability regardless of the merit of the underlying claim. There are three types of immunity defenses that may be raised in section 1983 litigation: sovereign immunity, which prohibits suits against the states; ${ }^{11}$ absolute immunity, which prohibits suits

and noting $1100 \%$ rise in cases brought under the statute between 1960 and 1970). Judge Aldisert concludes that the expanded reach of section 1983-generated claims endangers judicial economy and federalism. But see Eisenberg, Section 1983: Doctrinal Foundations and an Empirical Study, 67 CoRnell L. REv. 482 (1982). Professor Eisenberg argues that "section 1983 cases are not overwhelming the federal courts; trivial claims, involving little if any federal policy, do not dominate district court dockets, and courts are not, at the behest of state prisoners, eagerly overseeing minute details of prison life." Id. at 484. His study of section 1983 cases filed in the Central District of California leads him to believe "that the number of cases is only a fraction of what many of us have believed." Id. at 533 .

- Courts and commentators have expressed concern that the increased exposure of public officials to personal liability affects their performance negatively, which, in turn, has a deleterious effect on governmental operations. See, e.g., Butz v. Economou, 438 U.S. 478, 526-28 (1978) (Rehnquist, J., dissenting); Schuck, supra note 6. Schuck argues that an important goal of any system of liability and immunity for government decisionmakers should be to encourage officials "to execute their duties in a decisive, selfless, and socially beneficial manner." Id. at 285. According to Schuck, this policy objective of "vigorous decision-making" is disserved by imposing personal liability on officials because fear of liability causes them to try to minimize the risk of liability by engaging in "inaction, delayed action, formalism, and selection of the least risky decision alternative." Id. at 285, 313. See infra text accompanying notes 68-72.

${ }^{10}$ See Aldisert, supra note 8 (discussing statute as source of burdensome litigation that should often be in state, rather than federal, courts); Nahmod, The Mounting Attack on Section 1983 and the Fourteenth Amendment, 67 A.B.A. J. 1586 (1981) (discussing caseload concern-based attacks on the scope of section 1983).

ii The Supreme Court has held that the eleventh amendment bars suits in a federal court by a private party against a state if those suits seek to obtain "retroactive relief" by imposing "liability which must be paid from public funds in the state treasury." Quern v. Jordan, 440 U.S. 332, 337 (1979); see Edelman v. Jordan, 415 U.S. 651,663 (1974). Although the eleventh amendment bars a private party from obtaining such retroactive relief, a private party may still obtain prospective relief that enjoins state officials to conform their conduct to the requirements of federal law. Such an injunction may be obtained in federal court even though it has an "ancillary" effect on the state treasury. Quern, 440 U.S. at 337. The Supreme Court has also held that Congress did not intend section 1983 to overrule the traditional sovereign immunity of the states guaranteed by the eleventh amendment. Id. at 341-45.

The Court has held, however, that the eleventh amendment does not apply to local government units and has therefore permitted private parties to bring section $1983 \mathrm{ac}$ tions against municipalities. See Monell v. Department of Social Servs., 436 U.S. 658 (1978) (local governments not entitled to absolute sovereign immunity under section 
against the President, legislators, judges, and prosecutors acting within their official capacities, ${ }^{12}$ and qualified immunity, which is available to certain other public officials upon a showing that they acted in "good faith."1s

In June 1982, the Supreme Court, in Harlow v. Fitzgerald, ${ }^{14}$ redefined the standard to be used by courts in evaluating the availability of the qualified immunity defense. Before Harlow, the Court had never adequately clarified two important ambiguities in this immunity defense: the standard by which a defendant-official's good faith was to be tested ${ }^{15}$ and the degree to which the good faith inquiry was to be grounded in the factual context of each suit. ${ }^{16}$ Harlow ostensibly resolved these issues by holding that the good faith of an official seeking qualified immunity was to be measured against an "objective" standard. ${ }^{17}$ This objective inquiry was to rest upon a court's threshold determination, prior to discovery, whether the applicable law was sufficiently settled for a reasonable official to have guided her conduct by

1983 and may be sued for actions implemented under formal government policies or sanctioned by government usage); see also Owen v. City of Independence, 445 U.S. 622 (1980) (local government units not entitled to qualified immunity as a defense to section 1983 actions).

19 See Nixon v. Fitzgerald, 457 U.S. 731 (1982) (the President); Eastland v. United States Servicemen's Fund, 421 U.S. 491 (1975) (legislators); Stump v. Sparkman, 435 U.S. 349 (1978) (judges); Imbler v. Pachtman, 424 U.S. 409 (1976) (prosecutors).

1s Hence the term "qualified immunity." Qualified immunity is an affirmative defense that shields officials who acted in good faith from liability. Harlow v. Fitzgerald, 457 U.S. 800, 815 (1982). The Court has held that the scope of protection afforded by qualified immunity is affected by the function and the alleged actions of the individual defendant. See, e.g., Scheuer v. Rhodes, 416 U.S. 232, 247 (1974). ("[I]n varying scope, a qualified immunity is available to officers of the executive branch of government, the variation being dependent upon the scope of discretion and responsibilities of the office and all the circumstances as they reasonably appeared at the time of the action on which liability is sought to be based.").

14 457 U.S. 800 (1982).

16 See infra text accompanying notes 29-56. Several case notes have commented upon Harlow and its reformulation of the test for the determination of qualified immunity issues. See, e.g, Comment, Entity and Official Immunities Under 42 U.S.C. Section 1983: The Supreme Court Adopts a Solely Objective Test, 28 S.D.L. REv. 337 (1983) [hereinafter cited as Comment, Entity]; Note, Immunity: Eliminating the Subjective Element from the Qualified Immunity Standard in Actions Brought Against Govermment Officials, 22 WASHBURN L.J. 577 (1983) [hereinafter cited as Note, Immunity]; see also The Supreme Court, 1981 Term, 96 HARv. L. REv. 4 (1982) [hereinafter cited as Supreme Court, 1981 Term]. Other notes on Harlow have focused more closely on the distinctions drawn in the case between qualified and absolute immunity. See, e.g., Case Note, Degree of Immunity Applicable to Senior Aides of the President of the United States in Civil Actions Arising Under the Constitution: Harlow v. Fitzgerald, 1983 B.Y.U. L. REv. 426.

${ }^{16}$ See infra text accompanying notes 48-52.

17 Harlow, 457 U.S. at 815-20. See infra note 39 for definitions of "objective." 
it. $^{18}$

Harlow's redefinition of the qualified immunity defense has brought about "a quiet revolution in the law of official immunities."10 It is a revolution with a lurking dark side. Because Harlow has the potential to broaden dramatically the protection that the qualified immunity defense affords to public officials, it could undermine the significance of section 1983. Whether this happens will depend largely upon the lower courts' interpretation of Harlow's broad language redefining qualified immunity.

This Comment assesses Harlow's intended, actual, and potential impact upon the qualified immunity defense under section 1983. Part I relates the Supreme Court's development of section 1983 and the qualified immunity defense prior to Harlow. Part II discusses the competing policy concerns that must be balanced when, considering the appropriate scope of the qualified immunity defense. Part III examines how these policies led the Supreme Court to restructure the defense in Harlow. The Comment, in part IV, then reviews the various ways in which the lower courts are interpreting Harlow. It considers the implications of the varying approaches for the future of section 1983 litigation and advocates the adoption of the one approach that accomodates the policy concerns underlying Harlow, yet that still preserves the substantive viability of section 1983 as a vehicle for vindicating federal rights in federal courts.

\section{Development of The Section 1983 Qualified IMMunity Defense}

The defense of qualified immunity to liability under section 1983 is a product of judicial invention rather than statutory interpretation. The text of the statute does not suggest the availability of any such defense; ${ }^{20}$ rather, the defense derives from the common law doctrine of sovereign immunity, often stated as the maxim "the king can do no wrong."21 The modern judicial development and refinement of immunity doctrines has been spurred in large measure by the rise of suits against public officials under section $1983 .{ }^{22}$

18 Harlow, 457 U.S. at 815-20.

19 Saldana v. Garza, 684 F.2d 1159, 1163 n.15 (5th Cir. 1982), cert. denied, 103 S. Ct. 1253 (1983).

${ }_{20}$ See Eisenberg, supra note 8, at 504; see also Tenney v. Brandhove, 341 U.S. 367, 376 (1951). See supra note 1 for text of section 1983.

${ }_{21}$ See Scheuer v. Rhodes, 416 U.S. 232, 239-41 (1974). For a brief discussion of the different types of immunity and who may claim them, see generally Comment, Entity, supra note 15.

${ }_{22}$ See supra note 8 and accompanying text. 
To state a cause of action under section 1983, a plaintiff must allege a deprivation of a federal right by some persons, or person, acting under color of state or territorial law. ${ }^{23}$ Qualified immunity is thus an affirmative defense available to public officials in section 1983 cases. ${ }^{24}$ To avail herself of the defense, a defendant-official must prove that she acted in good faith, that is, that she "reasonably believed" that her action was lawful. ${ }^{25}$ The resolution of a defendant's claim of immunity often determines the outcome of the case. If her claim is upheld, the plaintiff loses. If the court rejects her immunity defense and the plaintiff establishes the requisite violation, the defendant cannot prevail unless she carries the difficult burden of proving that the plaintiff suffered no injury. ${ }^{2 B}$

Because the resolution of the immunity issue has such a direct bearing on the final disposition of a section 1983 action, the Supreme Court has struggled to define the contours of the good faith showing necessary for an official to claim qualified immunity. Harlow v. Fitzgerald $^{27}$ departs significantly from the approach taken in qualified immunity cases that preceded it by conferring greater protection upon public officials. To understand fully the dimensions of the "quiet revolution"28 that Harlow brought about, it is necessary to consider the case law upon which it drew.

\section{A. Case Law Preceding Harlow v. Fitzgerald}

In 1967 the Court first suggested that a public official, sued under section 1983 but unable to claim absolute immunity, might be entitled to claim a conditional, or qualified, immunity. In Pierson $v$. Ray, ${ }^{29}$ the Court considered the immunity claims of Mississippi police officers who had arrested the plaintiffs-a group of white and black clergy-

23 See supra notes 1 \& 4; see also Gomez v. Toledo, 446 U.S. 635, 640 (1980).

24 See supra note 6; see also Gomez v. Toledo, 446 U.S. 635, 640 (1980).

${ }^{25}$ Pierson v. Ray, 386 U.S. 547, 555 (1967).

${ }^{26}$ The injury that must be shown under section 1983 is a deprivation of a federal statutory or constitutional right. See supra note 1 for text of section 1983.

Even if the qualified immunity defense fails, a defendant may also escape liability if her action was not the "cause in fact" of the deprivation of the plaintiff's rights. For example, a difficult issue of cause in fact may arise in cases where "it is alleged that the defendant . . . failed to act to prevent the violation of plaintiff's constitutional rights by others." S. NAHMOD, supra note 2, at 86-87. Furthermore, some courts have applied another tort principle and required that the defendant's action be the "proximate cause" of the deprivation of plaintiff's rights. Id. at 83-86.

27457 U.S. 800 (1982).

${ }^{28}$ Saldana v. Garza, 684 F.2d 1159, 1163 n.15 (5th Gir. 1982), cert. denied, 103 S. Ct. 1253 (1983).

29386 U.S. 547 (1967). 
men-on charges of having breached the peace by using segregated facilities. ${ }^{30}$ The Court held that the policemen were entitled to assert the defense of qualified immunity because

[a] policeman's lot is not so unhappy that he must choose between being charged with dereliction of duty if he does not arrest when he has probable cause, and being mulcted in damages if he does .... [T] seem to require excusing him from liability for acting under a statute that he reasonably believed to be valid .... ${ }^{31}$

Although Pierson announced the availability of a qualified immunity defense conditioned upon some showing of "reasonable belief," it did not define the content of the defense. Instead, the Court remanded for the lower court to determine whether the police could have "reasonably believed" that the statute under which they arrested the clergymen was valid. ${ }^{32}$

The next case, Scheuer $v$. Rhodes, ${ }^{33}$ marked the Court's first effort to define the elements of the good faith that secures immunity from suit. Scheuer involved claims brought against the Governor of Ohio for his decision to call upon the National Guard in the Kent State demonstrations. ${ }^{34}$ The Court held that the Governor was entitled to assert a qualified immunity defense ${ }^{35}$ and then proceeded to discuss the content of that defense.

Scheuer's analysis of the defense focused upon the nature of the evidence to be considered in assessing an official's good faith. It did not, however, establish the standard against which the official's conduct was to be measured. Qualified immunity in general, the Court held, is conditioned upon "the existence of reasonable grounds" for the official to have believed, in good faith, "at the time and in light of all the circumstances," that her actions did not violate the plaintiff's rights. ${ }^{38}$
so Id. at $548-49$.
31 Id. at 555 .
s2 Id. at $557-58$.
s3 416 U.S. 232 (1974).

st Id. at 234. The suits also involved claims against other state officials and officers as well as enlisted members of the National Guard.

ss In Scheuer the Governor argued that he was entitled to absolute immunity from liability for his actions. The Court rejected this argument and stated that the protection from judicial review that would be afforded by absolute immunity would mean that section 1983 would be "drained of meaning." Id. at 248.

se Id. at 247-48. However, the Court declined to apply this standard in Scheuer because there was /not enough evidence to determine whether the defendants had acted in good faith. Id. at 250. The district court had ruled that the actions, although in form against the named individuals, were in substance and effect against the state and thus were barred by the eleventh amendment. The district court, therrefore, had dismissed 
The Scheuer test, then, was fact-oriented; determinations regarding immunity depended upon an evaluation of "all the circumstances" of the case. Evaluation of all the circumstances, in turn, depended upon the adequate development of a factual record. ${ }^{37}$ The implication of this fact-oriented evaluation of good faith was that courts would find it extremely difficult to dispose of the qualified immunity question at an early stage of the litigation - for example, prior to discovery.

While Scheuer's reasonableness test provided adequate guidance as to the evidence upon which the good faith determination was to depend, it was too vague to serve as a standard by which lower courts could judge the reasonableness of an official's actions. ${ }^{38}$ Scheuer did not specify whether evaluations of good faith should center on an "objective" inquiry into the extent to which the law or right allegedly violated should have been known by a reasonable official or, alternatively, on a "subjective" inquiry into the extent to which the defendant-official's actual state of mind at the time she acted could be characterized as one of good faith based upon a reasonable assessment of the circumstances and the applicable law. ${ }^{38}$ The Scheuer reasonableness test thus was suscep-

the action for lack of jurisdiction before the filing of an answer to any of the complaints. Id. at 234-35.

s2 Id. at 249-50.

ss One commentator noted that Scheuer left unanswered a number of questions: "did 'good faith' mean that government officials acted without malice or evil intent, that they affirmatively believed that they were acting within the law or the limits of their authority, or that they were following what they thought were lawful orders of their superiors?" Friedman, The Good Faith Defense in Constitutional Litigation, 5 HoFSTRA L. REV. 501, 511-12 (1977).

so The terms "objective" and "subjective" appear throughout discussions of qualified immunity; their precise definitions are thus crucial to immunity considerations. Yet, the terms are often used loosely. One commentator has characterized the "objective" inquiry as a requirement that a defendant have "reasonable grounds for ... belief in the legality of the challenged conduct" and the "subjective" inquiry as a requirement that the defendant have "good faith in fact." See S. NAHMOD, supra note 2, at 231.

The Supreme Court, in Wood v. Strickland, 420 U.S. 308 (1975), characterized the two concepts similarly. In discussing the subjective standard of good faith, the Court noted that a defendant should have acted "sincerely and with a belief that he is doing right," that a defendant should have had "permissible intentions," and that the defendant could not have acted with a "malicious intention to cause a deprivation of constitutional rights or other injury." Id. at 321-22. Regarding the objective component of the test for good faith, the Court said that the defendant could not disregard "settled indisputable law," had to know and respect "basic, unquestioned constitutional rights," and would be liable if she "knew or reasonably should have known that the action [she] took within [her] sphere of official responsibility would violate the constitutional rights" of the person affected. Id.

As used in this Comment, a subjective test for good faith will involve an inquiry into the defendant's actual knowledge of the law with which she is bound to comply, and her actual intent-malicious or sincere-for acting. A subjective inquiry, therefore, will depend heavily upon the facts and circumstances of any particular case. An objec- 
tible to different interpretations of the meaning of "good faith."40

The following year, in Wood v. Strickland, ${ }^{41}$ the Supreme Court attempted to clarify the Scheuer test by confronting directly the question whether the good faith necessary for qualified immunity should be characterized as objective or subjective. In Wood the qualified immunity issue arose in a suit brought by expelled school children against members of a local school board. ${ }^{42}$ The district court ruled that the board members were immune from suit because the students had not carried their burden of proving that the school board members had acted maliciously in deciding to expel them. ${ }^{43}$ The district court, therefore, applied an essentially subjective test to assess the board members' good faith.

On appeal the Eighth Circuit reversed, holding that the lower court's qualified immunity analysis rested upon an erroneous requirement of a showing of malice. ${ }^{44}$ It held that qualified immunity analysis should be objective, rather than subjective. Thus, to defeat a qualified immunity defense, the plaintiff had to prove that the officials' actions were objectively unreasonable, rather than prove that they were motivated by subjective ill-will or malice. ${ }^{45}$ Applying this standard, the circuit court held that, although the "[1]aw with respect to the rights of students is still developing," doctrines indicated that students could not "be given lengthy suspensions ... without being accorded substantive and procedural due process."'47

tive test, in contrast, will focus primarily on a legal determination of the clarity and settled nature of the law with which the defendant is required to comply. Her action is to be measured against that which would have been taken by a reasonable official in her position charged with knowledge of that law. These tests are neither mutually exclusive nor easily separable. See infra text accompanying notes 106-11.

10 See Section 1983 and Federalism, supra note 8, at 1212-13 (the term good faith "itself assumed a more objective or subjective meaning, depending upon which court was interpreting it").

41420 U.S. 308 (1975).

12 Wood involved the claims of two students claiming that the school board members violated their rights to due process, under color of state law, when they expelled the students for violating a school regulation that prohibited the use or possession of alcohol at school or school activities. Id. at 309-10.

4 Id. at 310 .

4t Strickland v. Inlow, 486 F.2d 186 (8th Cir. 1973), vacated sub nom. Wood v. Strickland, 420 U.S. 308 (1975).

15 Id. at 191 .

40 Id. at 189 .

17 Id. The district court's subjective analysis proved to be, on the facts of the case, more protective of the public officials than the objective analysis applied at the initial appellate level. In contrast the Supreme Court's adoption of an exclusively objective test in Harlow, 457 U.S. at 815-19, was interpreted by many commentators to foreshadow an expansion of the protection afforded public officials by the qualified immunity de- 
The contrast between the district and appellate court approaches to qualified immunity presented the Supreme Court with an opportunity to clarify Scheuer's reasonableness test. ${ }^{48}$ Unfortunately, the Court's opinion in Wood further muddied the analysis by combining the two approaches to create a qualified immunity standard that explicitly encompassed both subjective and objective factors. Good faith, the Court ruled, "necessarily contains elements of both" the subjective and objective tests. ${ }^{4 \theta}$ The Court required that a defendant seeking immunity have acted both with "permissible intentions," and without "ignorance or disregard of settled, indisputable law." inquiry was upon the motives and intentions of the defendant-official, essentially factual questions. In contrast the focus of the objective inquiry was upon whether the applicable law was settled or ambiguous, an essentially legal question. A court had to apply both tests to the challenged act before immunity attached to the defendant.

By imposing upon public officials a duty to know "basic, unquestioned constitutional rights," Wood's objective test significantly departed from the fact-intensive nature of the qualified immunity analysis prescribed in Scheuer. Under Scheuer an official's reasonableness was tested within the context of the facts and circumstances of each case. ${ }^{\mathbf{5 2}}$ Under Wood, however, an official's objective reasonableness was to be measured against the degree to which the law in question was knowable.

In Wood Justices Powell, Rehnquist, Blackmun, and Chief Justice Burger dissented ${ }^{53}$ because they believed that the restructured objective test imposed upon public officials an onerous duty to know the law,

fense. See, e.g., Supreme Court, 1981 Term, supra note 15, at 233-34. One should thus embrace with caution any notion that the label attached to the good faith test itself is sufficient to determine the coverage of the qualified immunity defense.

48 Although the Court treated the case as one presenting the question of school board members' immunity, the tests set forth in Wood were adopted as a "unitary" standard applicable to all claims of qualified immunity. S. NAHMOD, supra note 2 , at 229-31; see also Harlow, 457 U.S. at 815 n.25 ("Subsequent cases . . . have quoted the Wood formulation as a general statement of the qualified immunity standard.").

4 Wood, 420 U.S. at 321.

so Id. at 321-22.

s1 Id. at 322 .

s2 See S. Nahmod, supra note 2, at 231-36; see also The Supreme Court, 1974 Term, 89 HaRv. L. REv. 49, 219-25 (1975) (discussing Wood $v$. Strickland and Scheuer $v$. Rhodes).

ss Powell, the author of Harlow, concurred in part but dissented from that part of the majority opinion that set forth the new definition of good faith affording qualified immunity. The majority standard, Powell wrote, "appears to impose a higher standard of care upon public school officials, sued under $\$ 1983$, than that heretofore required of any other official." Wood, 420 U.S. at 327 (Powell, J., concurring in part and dissenting in part). 
forcing them to "act at the peril of some judge or jury subsequently finding that a good-faith belief as to the applicable law was mistaken and hence actionable." vere standard" would "significantly enhanc[e] the possibility of personal liability" and would discourage qualified persons from seeking public office. ${ }^{\mathrm{SB}}$ They therefore urged that the good faith inquiry continue to be governed by Scheuer. ${ }^{56}$

\section{B. Qualified Immunity Analysis Under Wood v. Strickland}

The Wood dissenters' fears were not realized. There were difficulties in the interpretation and application of the standard, ${ }^{87}$ but in practice the objective aspect of the Wood test tended to work "rather rigidly in a defendant's favor" because of its "peculiarly legal nature." In applying Wood lower courts measured the objective reasonableness of a section 1983 defendant's action against the state of the applicable law at the time of the defendant's alleged violation of that law. If a court found the law to have been unclear, it upheld the defendant's claim of immunity. Thus, the extent of protection afforded to public officials by Wood's objective analysis depended upon the degree of uncertainty that judges found in the law applicable to each particular case. Almost all legal issues, of course, could be labeled as unclear by judges wishing to

54 Id at 329. The majority did not perceive the standard to be problematic. It noted that defendants would not be "charged with predicting the future course of constitutional law.' "Id. at 322 (quoting Pierson v. Ray, 386 U.S. 547, 557 (1967)).

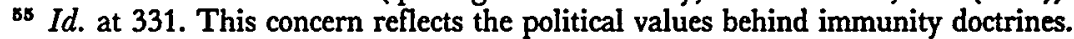
The juxtaposition of this concern with the majority's argument that "[a]ny lesser standard [of good faith] would deny much of the promise of $\$ 1983$," id. at 322 , reveals the inverse relationship between the breadth given to qualified immunity and the breadth given to section 1983.

${ }^{60}$ Scheuer, as characterized by the dissenters, presented a "considerably less demanding standard of liability." Id. at 330 (Powell, J., concurring in part and dissenting in part).

${ }_{87}$ See S. NaHmon, supra note 2, at 230, 258 (asserting that the objective part of the standard has caused "confusion and controversy" while the subjective part has been "applied with little difficulty."); see also Newman, Suing the Lawbreakers: Proposals to Strengthen the Section 1983 Damage Remedy for Law Enforcers' Misconduct, 87 YALE L.J. 447 (1978). Newman argues that the objective standard "involves nearly circular reasoning that promotes confusion and sometimes defeats meritorious claims." He gives an example:

[I] the plaintiff's own case requires him to show an arrest that was not reasonably based on probable cause, what does the defense mean? Surely the officer could not reasonably believe that there was probable cause for an unlawful arrest, for an unlawful arrest is by definition an arrest for which a prudent police officer could not reasonably believe there was probable cause.

Id. at 460 .

${ }^{88}$ S. NAHMOD, supra note 2, at 237-38. 
do so. ${ }^{80}$ The very aspect of the objective test that Justice Powell found threatening to public officials-the uncertain nature of the law ${ }^{60}$ - often worked to the advantage of public officials.

The pro-defendant propensity of the Wood objective test could also be enhanced if judges narrowly defined what applicable law was either "settled" or "unquestioned," thus contracting the range of law about which a defendant would have a duty to know. ${ }^{61}$ In Procunier $v$. Navarette ${ }^{62}$ the Court adopted precisely such a narrow view of "settled law."

Procunier involved a prison inmate's section 1983 claims against California prison officials. The prisoner alleged that he had been deprived of his rights under the first, fifth, and fourteenth amendments (as well as under California prisoner-mail regulations) by the failure of prison officials to mail his various legal correspondence. ${ }^{63}$ The Court held that in order to find that the officials had violated "clearly established law" in withholding the mail privileges, the plaintiff had to demonstrate a close factual conformity between the case at bar and the previous case law establishing the illegality of the action at issue. After canvassing the applicable cases, the Court ruled that the law was not sufficiently established to justify holding that the prison officials had acted unreasonably. The defendant's claim of qualified immunity was upheld. ${ }^{\text {ot }}$

Procunier thus rendered the objective prong of the Wood qualified immunity analysis considerably more protective of officials by requiring a close similarity between the facts of a case at bar and the facts of cases establishing applicable law. ${ }^{65}$ In so requiring, Procunier limited

w Nahmod has noted, "[U]nless there is a case on all fours from the relevant circuit or the Supreme Court, most legal issues can be made to appear relatively uncertain." Id. at 238.

* Powell argued, "One need only look to the decisions of this Court-to our reversals, our recognition of evolving concepts, and our five-to-four splits-to recognize the hazard of even informed prophecy as to what are 'unquestioned constitutional rights." " Wood, 420 U.S. at 329 (Powell, J., concurring in part and dissenting in part).

-1 See, e.g., Gilliard v. Oswald, 552 F.2d 456 (2d Cir. 1977). There, the dissenting judge argued that the majority's granting of immunity on the grounds that the law was not settled was mistaken. He wrote, "The law in this area at the relevant time was about as 'settled' and 'unquestioned' as law can ever be in our system of case-by-case development of the contours of constitutional rights." Id. at 465, quoted in S. NAFMOD, supra note 2, at 239.

434 U.S. 555 (1978).

a Id. at 556-58. The Supreme Court granted certiorari to consider issues of law pertinent to the defendant's good faith claims.

See id. at 562-64.

4. See S. Natimod, supra note 2, at 245 (noting that Procunier indicated that good faith requirements "could eventually be severely limited by the Court to those situations where there is a case on point setting forth the existence of a constitutional 
the range of law an official was held to know upon pain of losing her immunity. The Procunier gloss met the objections of the Wood dissenters who had feared the objective test would prove unduly burdensome on public officials. Wood's apparently strict "duty to know" could be applied in a manner quite unforeseen by those dissenters.

Such a narrow view could adversely affect plaintiffs in two ways. It could foreclose holdings favorable to those who bring suit under section 1983 and who press rights that may be construed as unsettled. It could also prove unduly restrictive of plaintiffs' claims in suits involving settled rights that arise within an unusual factual context. ${ }^{68}$ While such redefinitions of the contours of the qualified immunity defense may further certain policies underlying that defense, they may do so at the expense of competing policies that the section 1983 cause of action was created and expanded to foster. ${ }^{67}$ To understand the nature of the conflict, it is necessary to understand the policies that the Court has attempted to further in its development of the qualified immunity defense.

\section{Policies Underlying the Development of the Qualified IMMUNITY DEFENSE}

The cases in which the Supreme Court has considered the issue of qualified immunity reflect consistent policy concerns, the primary one being a desire to permit public officials to carry out their tasks without fear of potential liability. ${ }^{68}$ In developing the qualified immunity defense, the Court expressly has attempted to minimize the adverse effect upon a public official's decisionmaking that results from the threat of

right"); see also Note, Basis of Liability in a Section 1983 Suit: When Is the State-ofMind Analysis Relevant?, 57 IND. L.J. 459, 468-69, 476-77 (1982) (noting that Procunier's analysis turns upon whether the right is clearly established, yet there are no guidelines concerning the determination of clearly established rights, and the courts are reluctant to find an injury is based upon such a right).

Procunier's narrow view of what constitutes a clearly established right has been criticized as giving officials one "free" constitutional violation. See, e.g., Freed, Executive Official Immunity For Constitutional Violations: An Analysis and a Critique, 72 Nw. U.L. REv. 526, 558-59 (1977) (suggesting that instead of using Procunier's narrow "settled law" approach, the object of qualified immunity standards should be to eliminate "surprise liability" by requiring officials to act reasonably).

of See Section 1983 \& Federalism, supra note 8, at 1216-17 (arguing that Wood v. Strickland's objective test should be used in conjunction with an overall reasonableness evaluation such as Scheuer $v$. Rhodes's immunity test, and warning that, otherwise, section 1983 would be significantly cut back by immunity obtained through "resort to formalistic arguments that the right violated was not of sufficiently settled legal status to warrant an imputation of malice").

${ }^{67}$ See infra text accompanying notes 76-79.

68 See, e.g., Butz v. Economou, 438 U.S. 478, 526-27 (1978) (Rehnquist, J., dissenting); Schuck, supra note 6, at 314-15. 
personal liability. ${ }^{69}$ The Court intended the qualified immunity defense to ensure that public officials could act freely and to reduce the likelihood of "[p]ublic officials . . . fail[ing] to make decisions when they are needed or not act[ing] to implement decisions when they are made "70

Without such a protective doctrine, commentators have noted, the threat of personal liability might well induce self-protective behavior by officials that would hamper their decisionmaking. Such behavior might manifest itself in "inaction, delay, formalism, and a[n adverse] change in the character of the decisions." in the case of low-level officials-for example, police officers-who often must make difficult "judgment calls" without the opportunity for prior reflection or guidance. ${ }^{72}$

In addition to furthering the public interest by facilitating effective government through unhampered decisionmaking, qualified immunity also serves related efficiency policies. Efficient government is enhanced, it is argued, by conserving the time and money of officials who might otherwise be mired in extended and perhaps frivolous litigation. ${ }^{73}$ The qualified immunity doctrine also reflects increasing concern about the growth of federal court dockets. ${ }^{74}$ Section 1983 is associated with such

69 See, e.g, Scheuer v. Rhodes, 416 U.S. 232, 240-42 (1974) (describing need for and development of immunity doctrine).

${ }^{70}$ Id. at 241-42.

71 Schuck, supra note 6, at 308.

72 See id. at 295-305.

73 See Harlow v. Fitzgerald, 457 U.S. 800, 814 (1982); Comment, Entity, supra note 15, at 339, 354; cf. Pierson v. Ray, 386 U.S. 547, 554 (1967) (A judge "should not have to fear that unsatisfied litigants may hound him with litigation charging malice or corruption.").

"See supra note 8.

Increasing caseloads have become a major cause of complaint and worry for the federal judiciary. Among the voices sounding alarms about the courts' workload is that of Justice Powell, author of the Harlow opinion. In a speech to the New York City Bar, for example, Powell warned that "our system of justice is in trouble. The problems are legion." He went on to attribute many of the problems to "court overload," which he characterized as an "ever-widening stream of litigation." Powell, Orison S. Marden Memorial Lecture, 33 REC. A.B. CITY N.Y. 458-59 (1978).

Powell's speech also suggested that "claims under Section 1983" were among the "underlying causes of court overload." Id. at 459,465 . He also expressed his feelings concerning section 1983 litigation in his dissent in Maine v. Thiboutot, 448 U.S. 1 (1980). The majority in Thiboutot held that a section 1983 claim could be based on violation of federal statutory rights and need not allege a violation of a constitutional right. Powell's dissent warned,

No one can predict the extent to which litigation arising from today's decision will harass state and local officials; nor can one foresee the number of new filings in our already overburdened courts.

[T]here is some evidence that $\S 1983$ claims already are being ap- 
concerns because of the "explosion" of such cases that followed Monroe v. Pape. ${ }^{7 \mathrm{~s}}$

These policies underlying qualified immunity, however, may conflict with the policies supporting the section 1983 cause of action. Section 1983 was enacted to restrain public officials from abusing their positions in violation of the law. ${ }^{78}$ It does so by deterring officials from engaging in such abuses and by providing a remedy to compensate victims of unconstitutional official behavior. ${ }^{77}$ This intended restraint is the very essence of the section that "enforce[s] provisions of the Fourteenth Amendment against those who carry a badge of authority of a State and represent it in some capacity." "78 Yet, when a court terminates a section 1983 action by immunizing a defendant-official, many plaintiffs have no alternative cause of action and are thus left without remedy for violations of their constitutional rights. ${ }^{7 \theta}$

In the qualified immunity cases, the Court has struggled to balance these competing policies. Harlow $v$. Fitzgerald ${ }^{80}$ represents the latest, and most definitive, attempt to achieve a just balance.

\section{Harlow v. Fitzgerald}

In Harlow v. Fitzgerald ${ }^{\mathbf{8 1}}$ Ernest Fitzgerald alleged that Bryce Harlow and Alexander Butterfield, senior White House aides to former

pended to complaints solely for the purpose of obtaining fees in actions where 'civil rights' of any kind are at best an afterthought.

448 U.S. at 23-24 (Powell, J., dissenting).

${ }^{28}$ See supra note 8.

${ }^{78}$ See supra note 2; see also Monroe v. Pape, 365 U.S. 167, 174-76 (1961) ("It was ... the failure of certain States to enforce the laws with an equal hand that furnished the powerful momentum behind this "force bill," " and the remedy ultimately created was directed "against those who representing a State in some capacity were unable or unwilling to enforce a state law.").

77 Monroe, 365 U.S. at 174-77.

${ }^{78} \mathrm{Id}$. at 172.

79 See, e.g., Butz v. Economou, 438 U.S. 478, 506 (1978) (stating that where public officials have abused their power, a suit for damages may be the most feasible method of compensating the injured party); see also Bivens v. Six Unknown Fed. Narcotics Agents, 403 U.S. 388, 410 (1971) ("For people in Bivens' shoes it is damages or nothing.").

${ }^{80} 457$ U.S. 800 (1982).

81457 U.S. 800 (1982). Harlow was not brought under section 1983 but was instead a "Bivens-type action." While an action brought under section 1983 is against state officials, a "Bivens-type" action is brought against federal officials. See Bivens v. Six Unknown Fed. Narcotics Agents, 403 U.S. 388 (1971); see also Butz v. Economou, 438 U.S. 478, 504 (1978) (holding that it is "untenable" to distinguish between suits brought against state officials and suits brought against federal officials for purposes of immunity analysis). Harlow's modification of qualified immunity was, however, explicitly made applicable to immunity defenses brought under section 1983 as well as in Bivens actions. See Harlow, 457 U.S. at 818 n.30. 
President Nixon, had conspired with Nixon ${ }^{82}$ to dismiss Fitzgerald from his post as an Air Force management analyst, to cover up his unlawful discharge, and to prevent his re-employment. ${ }^{83}$

The Court held that Harlow and Butterfield were entitled only to a qualified, rather than absolute, immunity defense. ${ }^{84}$ The Court then modified the defense by basing the question of the good faith that entitled officials to qualified immunity solely upon an objective inquiry. Under Harlow the qualified immunity defense shields "government officials performing discretionary functions . . . from liability for civil damages insofar as their conduct does not violate clearly established statutory or constitutional rights of which a reasonable person would have known." "8s

The majority opinion by Justice Powell clearly set forth the policy concerns that impelled the Court to modify the good faith test. Claims against federal or state officials, Powell wrote,

frequently run against the innocent as well as the guilty-at a cost not only to the defendant officials, but to the society as a whole. These social costs include the expenses of litigation, the diversion of official energy from pressing public issues, and the deterrence of able citizens from acceptance of public office. $^{86}$

A subjective qualified immunity test subverted these policies, Powell noted, because it posed a basically factual question. Answering such a question might well "entail broad-ranging discovery and the deposing

(22 Nixon was named in a companion case, Nixon v. Fitzgerald, 457 U.S. 731 (1982). In Nixon v. Fitzgerald, the Court held that the President was entitled to absolute immunity from liability for all actions taken within the "outer perimeter" of his official duties.

s3 Fitzgerald testified before a congressional committee, alleging cost overruns in defense contracts; his testimony was a source of much embarrasment for the Defense Department. He was subsequently discharged from his job, purportedly as a consequence of the reorganization of his department. Fitzgerald alleged that the dismissal was, in fact, retaliation for his congressional testimony. See Harlow, 457 U.S. at 80206; see also Nixon v. Fitzgerald 457 U.S. at 733-39.

Harlow and Butterfield argued that they were entitled to absolute immunity derived from the President's immunity because the President "must delegate a large measure of authority to execute the duties of his office [and] . . recognition of derivative absolute immunity is made essential by all the considerations that support absolute immunity for the President himself." The Court disagreed with their analysis and held, instead, that the aides were entitled only to qualified immunity. See Harlow, 457 U.S. at 810 .

88 Harlow, 457 U.S. at 818 . The Court bluntly set forth its motive for changing the test: "The subjective element of the good faith defense frequently has proved incompatible with our admonition . . . that insubstantial claims should not proceed to trial." Id. at 815-16.

80 Id. at 814 . 
of numerous persons, including an official's professional colleagues."

The subjective inquiry not only had the potential for requiring extensive discovery, but it also inhibited the expeditious disposition of claims on summary judgment because "an official's subjective good faith has been considered to be a question of fact that some courts have regarded as inherently requiring resolution by a jury." 88 In sum the Court reasoned that wide-ranging investigations of a public official's mental state at the time she acted were "peculiarly disruptive" to the operation of government. ${ }^{89}$ It therefore held that an official would no longer be required to demonstrate subjective good faith to establish a qualified immunity defense.

Having discarded the subjective strand of qualified immunity analysis, embraced in Wood $v$. Strickland, ${ }^{90}$ the Court proceeded to modify significantly the objective strand that remained. Again emphasizing expedience, the Court held that discovery regarding the merits of a claim should not proceed until an official's claim of qualified immunity had been tested against an objective standard. This evaluation of good faith could not be made, moreover, until a court identified "the currently applicable law" with which an official was required to comply and determined "whether that law was clearly established at the time an action occurred." This new formulation of the objective strand of qualified immunity analysis, Powell explained, was expressly designed to "avoid excessive disruption of government and permit the resolution of many insubstantial claims on summary judgment."

In Harlow Justice Powell thus relied on the objective test to accomplish precisely the opposite of what he had feared from the application of such a test in Wood. Powell had then vigorously dissented because he believed the test exposed defendants to an increased risk of liability. ${ }^{93}$ In Harlow, however, he reshaped the objective test to increase the protection afforded to public officials by qualified immunity. The defense was henceforth to function as a mechanism for cutting off insubstantial claims and thereby to reduce the burdens of section 1983 litigation upon both defendant-officials and federal courts.

${ }^{87}$ Id. at 817 . It should also be noted that the Court may have been considering the toll of section 1983 litigation upon the operations of the judicial, as well as the executive, branch of government. Justice Powell, the author of Harlow, has frequently expressed concern regarding the burden on the federal courts posed by this type of litigation. See supra note 74 and accompanying text.

${ }^{8}$ Harlow, 457 U.S. at 816.

so Id. at 817.

so 420 U.S. 308 (1975); see supra notes 49-52 and accompanying text.

91 Harlow, 457 U.S. at 818.

92 Id.

9s See supra notes 53-56 and accompanying text. 
Harlow's redefinition of the objective test illustrates the impact excessively narrow views of "settled law," such as that expressed in Procunier $v$. Navarette, ${ }^{94}$ have had on qualified immunity analysis. This reformulation of the seemingly strict Wood $v$. Strickland objective test into a device that favors defendants was made possible only because this groundwork had already been laid. With Harlow the development of the qualified immunity defense has culminated in the adoption of a new objective standard that serves as a conscious device for cutting off plaintiffs' claims.

\section{A. Application of the Harlow Standard}

Under Harlow qualified immunity analysis measures the "objective reasonableness of an official's conduct" by "reference to clearly established law." must then decide whether the law regarding those issues was clearly established at the time of the defendant's actions. If the judge determines that the law was not clearly established, then the defendant will be granted immunity from suit. If the judge determines that the law in question was clearly established, then "the immunity defense ordinarily should fail." ${ }^{\text {98 }}$ A public official who acted in violation of such established law may still claim immunity, however, if she claims "extraordinary circumstances and can prove that [she] neither knew nor should have known of the relevant legal standard." post-Harlow qualified immunity claims, is to "turn primarily on objective factors."

Whether a defendant may successfully claim qualified immunity after Harlow therefore depends upon a court's threshold, pre-discovery determination whether the law with which she was expected to comply was "clearly established." engendered difficulties under the objective part of Wood $v$. Strickland's qualified immunity test. ${ }^{100}$ Although the Court, in Harlow, was presumably aware of the confusion created by Wood, it did not clarify the phrase "clearly established law." The Court instead noted, "[W]e need not define here the circumstances under which the 'state of the law'

of 434 U.S. 555 (1978).

${ }^{85}$ Harlow, 457 U.S. at 818.

6 Id. at 818-19.

Id Id at 819.

23 Id. at 818-19. A defendant may still avoid liability even without immunity if the plaintiff cannot demonstrate an injury.

Id. at 818 .

100 See supra text accompanying notes $48-51$ \& 57. 
should be "evaluated by reference to the opinions of this Court, of the Courts of Appeals, or of the local District Court.' "101 Thus, the Court gave little explicit guidance to the lower courts regarding interpretation and application of the new qualified immunity test.

Nevertheless, Harlow's language provides some clues as to the nature and scope of the threshold legal determination that the Court envisioned. The opinion implies that a court should require that there be some degree of factual correspondence between applicable precedents and the case to be determined. Thus the Court's observation that a defendant may not "fairly be said to 'know' that the law forbade conduct" if that conduct had "not [been] previously identified as unlawful"102 suggests that the factual contexts of the relevant case law should bear sufficient similarity to the instant factual context to inform the official that her conduct was unlawful.

The Court left open, however, the critical question of the degree to which the facts of a plaintiff's case must correspond to the facts of prior cases in order to demonstrate that the law in question was established and thereby defeat a defendant's claim of qualified immunity. As was made evident by Procunier and other objective immunity analyses under the Wood standard, the degree of factual correspondence required to classify relevant law as "clearly established" can be dispositive of whether a claim of qualified immunity will survive a motion for summary judgment. ${ }^{108}$

The question appears to be even more critical under Harlow because the Court has mandated that this determination of factual correspondence be made at the very earliest stage of the litigation, before discovery. ${ }^{104}$ It may not be possible, however, for lower courts to comply with this mandate. ${ }^{105} \mathrm{~A}$ court may not make its "threshold determination" until it has first been presented with a claim of qualified immunity. Such a claim will often arise on a motion for summary judgment, which will, in and of itself, halt discovery. The court's ruling

101 Harlow, 457 U.S. at 818 n.32 (quoting Procunier v. Navarette, 434 U.S. 555, 565 (1978)). For a discussion of the confusion wrought by the Wood formulation, see $S$. NAHMOD, supra note 2, at 230.

102 Harlow, 457 U.S. at 818.

10s See supra text accompanying notes 61-65.

104 Harlow, 457 U.S. at 818.

105 Some lower courts have also noted that resolution of certain cases will require consideration of factual issues. See, e.g., Gannon v. Daley, 561 F. Supp. 1377, 1388 (N.D. Ill. 1983). Furthermore, cases involving issues such as probable cause for arrest necessarily involve some consideration of underlying factual questions.

The concurrence in Harlow acknowledges that consideration of factual issues may be necessary to determine what a defendant knew concerning the law she allegedly violated. See Harlow, 457 U.S. at 821 (Brennan, J., concurring). 
on the motion, however, may well depend upon whether the plaintiff can show that the facts of her case correspond sufficiently to the facts of prior cases to justify holding the defendant liable for non-compliance with "established law." Such a showing, however, may in turn depend upon discovery and development of the factual aspects of the case, which Harlow appears to preclude.

This internal inconsistency-prohibition of discovery during a threshold determination that may require development of a factual record-created sufficient ambiguity in the majority opinion to enable the concurring Justices to claim that they were agreeing with the majority, when in fact they were advocating a substantially different, pro-plaintiff standard.

\section{B. The Harlow Concurrence}

The concurring opinion of Justices Brennan, Marshall, and Blackmun in Harlow, although superficially in agreement with the majority, presents a qualified immunity analysis that could produce results very different from those contemplated by the majority. ${ }^{106}$ The concurrence, authored by Justice Brennan, begins by noting its agreement "with the substantive standard announced by the Court today, imposing liability when a public-official defendant "knew or should have known' of the constitutionally violative effect of [her] actions."107 At this point, however, the substantive agreement ends. The concurrence interprets the majority standard as denying protection to any official who "actually knows that [she] was violating the law," even if her knowledge could not "'reasonably have been expected" " by a judge

${ }^{100}$ The majority opinion in Harlow was joined by eight of the nine Justices; only Chief Justice Burger dissented, arguing that aides were entitled to absolute immunity. 457 U.S. at 822-29 (Burger, C.J., dissenting).

There were three concurrences in Harlow. One, by Justice Rehnquist, was very brief, noting only that the holding in Butz v. Economou, 438 U.S. 478 (1978), should be re-examined. Harlow, 457 U.S. at 822 . In Butz Rehnquist dissented in part, arguing that federal executive officials were entitled to absolute, rather than qualified, immunity. See Butz, 438 U.S. at 517-30 (Rehnquist, J., dissenting in part).

Another concurrence, by Justices Brennan, White, Marshall, and Blackmun, emphasized that their votes in Harlow did not imply any agreement with the grant of absolute presidential immunity given in Nixon v. Fitzgerald. See Harlow, 457 U.S. at 821-22 (Brennan, J., concurring).

The first concurrence appearing in the text, to which this Comment will refer simply as "the concurrence," was joined by Justices Brennan, Marshall, and Blackmun. It sets forth a different interpretation of the new qualified immunity test. See id. at 820-21 (Brennan, J., concurring). Although the divergence in interpretation appears slight, it makes room for an approach to qualified immunity analysis that is radically different from that of the majority. See infra text accompanying notes 108-11.

107 Harlow, 457 U.S. at 820-21 (Brennan, J., concurring). 
making the threshold objective determination of established law. ${ }^{108}$ The concurrence focuses upon the defendant's actual knowledge; thus Justice Brennan observes that "it seems inescapable to me that some measure of discovery may sometimes be required to determine exactly what a public-official defendant did 'know' at the time of [her] actions."109 For the concurring Justices discovery and factual analysis would still be necessary, at least in some cases, to make the mandated threshold determination of immunity issues. ${ }^{110}$

The concurrence's emphasis on actual knowledge and particular factual contexts suggests that its version of objective qualified immunity analysis actually imports into the Harlow objective inquiry elements of the Wood $v$. Strickland subjective standard that the Harlow majority discarded. The qualified immunity test, as the concurrence characterized it, calls for an inquiry into the defendant's state of mind, turning upon what the defendant knew, as well as what the law said. According to the concurrence, a defendant-official's good faith would be evaluated within the factual context of a particular case, rather than by exclusive reference to the legal context defining the issues of the case. ${ }^{111}$

The analysis of the concurrence offers lower courts a choice re-

${ }^{108}$ Id. at 821.

109 Id.

110 See id. This emphasis contrasts sharply with that of the majority opinion with which the concurring Justices are ostensibly in agreement. The majority opinion allowed only in the most grudging terms that a factual inquiry into a defendant's knowledge might, in some cases, be necessary: only "if the official pleading the defense claims extraordinary circumstances and can prove that [she] neither knew nor should have known of the relevant legal standard." Even in this extraordinary case, "the defense would turn primarily on objective factors." Harlow, 457 U.S. at 819 (majority opinion).

${ }^{111}$ See supra note 39 and accompanying text (discussing the difference between subjective and objective analyses).

The contrast between the interpretations of the majority and the concurrence highlights the ambiguous nature of the terms "objective" and "subjective." In the concurrence an "objective" test is made to encompass an inquiry into a defendant's state of mind, that is her actual knowledge. Such an inquiry would seem characteristic of a subjective test.

The concurrence characterized the state of the law that confers immunity as "so ambiguous at the time of the alleged violation that it could not have been "known." Harlow, 457 U.S. at 821 (Brennan, J., concurring). The implication is that there may be a level of somewhat ambiguous law-not "so ambiguous .... that it could not have been "known" "-at which liability may still be imposed. Id. (emphasis added). If this is so, then the concurrence essentially would hold that a defendant may be required to know, or acquire knowledge of, the law. Such a requirement, at the least, loudly echoes the standard originally enunciated in Wood $v$. Strickland: a duty to know and act within the law. See Wood, 420 U.S. at 321-22.

Justice Powell, author of Harlow, strongly objected to the Wood qualified immunity standard. See supra note 54 and accompanying text. The concurrence's return to at least some of the subjective elements of the old standard suggests more distance between it and the Harlow majority than the concurrence admits. 
garding the application of Harlow's redefined standard. In searching out the applicable law, they may look to a broad or narrow range of precedent. In defining the evidence necessary to make this threshold determination, they may look solely to the law or, alternatively, to the official's knowledge of the law as revealed by the particular factual context of the case. The choice the lower courts make may well determine whether many plaintiffs can continue to rely on section 1983 to vindicate their constitutional claims in federal courts.

\section{QUalified Immunity Since Harlow v. Fitzgerald}

In order to apply a standard that uses "clearly established law" as its reference point, courts must understand the content of that category. Harlow v. Fitzgerald ${ }^{112}$ attempted to offer some guidance to the lower courts by describing the authorities to which a court might look in determining whether the applicable law was "clearly established"113: opinions from the Supreme Court, all circuit courts, and the local district court. 114

Courts have taken varying approaches in their consideration of this relatively straightforward suggestion. Some courts have held the extreme view that only Supreme Gourt opinions should be considered; others have searched diligently through all levels of the federal system from a variety of jurisdictions. ${ }^{115}$ Similarly, courts have differed over how they should respond to an absence of applicable case law. Some courts have regarded the absence of case treatment as a sign that the law governing the issues in question is not "established," even when the applicable issue or statute is arguably clear. ${ }^{116}$

112457 U.S. 800 (1982).

113 Id. at 818 n.32 (citing Procunier v. Navarette, 434 U.S. 555, 565 (1978)).

124 Id.

${ }_{116}$ Compare, e.g., Crowder v. Lash, 687 F.2d 996, 1001-02 (7th Cir. 1982) (considering Supreme Court cases, as well as cases from various courts of appeals and district courts, to determine whether the law with respect to certain behavior by prison officials was clearly established) with Johnson ex rel. Johnson v. Brelje, 701 F.2d 1201, 1210-11 (7th Cir. 1983) (considering only one Supreme Court case in determining whether law was clearly established).

116 See Estes-El v. New York, 552 F. Supp. 885 (S.D.N.Y. 1982). In Estes-El, the plaintiff was arrested, without a warrant, by the defendants, environmental conservation officers, for fishing without a license. New York statutes provided such officers with the power to make warrantless arrests when a misdemeanor was committed in their presence; fishing without a license was classified as an "infraction," not a misdemeanor. The court was persuaded, however, that the powers of environmental conservation officers were unclear because another New York statute gave those officials police officer status, and police officers can arrest persons for "infractions." In the absence of court interpretations of environmental conservation officers' powers, the court held that the defendants had acted in "good faith" believing their actions to have been authorized. Id. at 888. Compare Heslip v. Lobbs, 554 F. Supp. 694 (E.D. Ark. 1982) (in 
Harlow did not even attempt to resolve, however, the most difficult question that is faced by a court attempting to apply the redefined qualified immunity standard: the extent to which courts should require a correspondence between the facts of "establishing" cases and the facts of the case under consideration. ${ }^{117}$

In the absence of adequate guidance, lower courts have taken three approaches to this problem. The first demands a relatively strict factual correspondence between the cases establishing law and the case at hand. ${ }^{118}$ The second demands less factual correspondence; it recognizes a duty on the part of defendant-officials to apply general legal principles to specific factual situations. ${ }^{119}$ The third demands that officials discern trends establishing general principles of law and apply those principles, when required, to particular situations. ${ }^{120}$ The approach a court chooses may be dispositive of the plaintiff's section 1983 claim.

\section{A. The First Approach: Strict Factual Correspondence}

The first approach requires a tight factual fit between cases establishing the applicable law and the case under consideration. Before they will characterize law as clearly established, courts taking this approach require that there be cases from the proper jurisdiction closely on point. ${ }^{121}$

determining whether defendant officers validly arrested the plaintiff for public drunkenness in a private home, court noted that the meaning of "public place" had only been construed in one case, which gave little aid in the instant case; therefore, the court held, the law was not clearly established, and defendants were entitled to immunity) with Benford v. American Broadcasting Cos., 554 F. Supp. 145, 153-54 (D. Md. 1982) (denying defendants' claim that Federal Eavesdropping Statute provided no clear standard).

${ }^{117}$ See supra text accompanying notes 101-03. For the confusion thereby engendered, see, e.g., Hixon v. Durbin, 560 F. Supp. 654, 664-65 (E.D. Pa. 1983) ("Unfortunately, in announcing the new test for qualified immunity in Harlow, the Supreme Court expressly declined to define what criteria a rule of law would have to meet in order to be deemed 'clearly established' ....." The court continued, "Presumably, every principle of law which is essential to the conclusion that the defendant violated plaintiff's rights must be 'clearly established' for the qualified immunity defense to fail." The court wondered, "Is the defense intended to establish a 'one bite' rule for government officials, so that they will be protected from liability for damages until another official has been held to have violated the Constitution in a case involving identical factual circumstances?" (citation omitted)).

118 See infra text accompanying notes 121-38.

110 See infra text accompanying notes 139-53.

120 See infra text accompanying notes 154-71.

121 See, e.g., National Black Police Ass'n v. Velde, 712 F.2d 569, 576 (D.C. Cir. 1983) (defendants did not violate clearly established rights under Title VI, although they did not necessarily comply with the statute); Saldana v. Garza, 684 F.2d 1159, 1165 (5th Cir. 1982), cert. denied, 103 S. Ct. 1253 (1983) (an arrest must be "so illegal" as to violate clearly established law before immunity will be denied); Piccollela 
This approach was used in Calloway v. Fauver. ${ }^{122}$ The plaintiffs were prison inmates involuntarily placed in indefinite protective custody. ${ }^{123}$ They alleged that the protective custody-in facilities far less desirable than those inhabited by the general prison population-constituted a deprivation of statutory and due process rights. They based their claim on the lack of a hearing regarding their initial confinement in protective custody, the absence of hearings regarding the continuation of their confinement, and, when they finally were accorded a hearing by court order, the defendants' use of previously undisclosed evidence. ${ }^{124}$

Regarding the defendants' claims of qualified immunity, the district court began by noting that the law applicable to the case had been developing since 1974, when the Supreme Court first defined the nature and scope of an inmate's due process rights to a hearing. ${ }^{125}$ In that year the Court held in Wolff $v$. McDonell ${ }^{\mathbf{1 2 6}}$ that an inmate's liberty interests were implicated by disciplinary hearings and transfers to security units and that prison authorities were thus required to comply with procedural due process requirements. ${ }^{127}$

In Calloway the district court found that the prison authorities had in fact violated the plaintiffs' due process rights; the prisoners were entitled to "an annual hearing complying with Wolff $v$. McDonnell standards to enable [them] to contest the continued need for protective custody." ${ }^{128}$ Nevertheless, the court upheld the defendants' claim of immunity, on the basis of the Harlow standard, because the plaintiffs' rights to such hearings had not been clearly established at the time the

v. Rieck, 555 F. Supp. 27, 28 (S.D.N.Y. 1982) (defendants entitled to qualified immunity where they instructed bank to deny access to a safe deposit box before a warrant was obtained despite earlier case, United States v. Place, 660 F.2d 44 (2d Cir. 1981), cert. denied, 457 U.S. 1106 (1982), which held that prolonged warrantless seizure of baggage was illegal, because the facts of the case at bar were not deemed similar to those of Place).

This type of analysis is reminiscent of judicial treatment of the objective standard in Wood v. Strickland, 420 U.S. 308 (1975). See supra notes 50-55 and accompanying text. It also recalls Procunier v. Navarette, 434 U.S. 555 (1978). See supra notes 62-65 and accompanying text.

122544 F. Supp. 584 (D.N.J. 1982).

123 The protective custody was deemed necessary because plaintiffs had been involved in the killing of the leader of a religious sect to which a large faction of the prison's inmates belonged. That faction had fought a rival religious sect to which the plaintiffs belonged. Prison officials believed the plaintiffs would be in great peril in light of plans by the first faction to avenge the death of its leader if the plaintiffs were returned to the general prison population. Id. at 588-92.

${ }^{124}$ Id. at 587.

125 Id. at 607.

128418 U.S. 539 (1974).

127 Id. at $557-58$.

128 Calloway, 544 F. Supp. at 607. 
rights were violated. ${ }^{120}$

The court's decision that the law defining the plaintiffs' rights was not "clearly established" rested on the ground that, notwithstanding the general guidelines in Wolff, no Supreme Court case had addressed the specific issue of whether an inmate was entitled to periodic hearings regarding the continuation of involuntary, long-term, protective custody. ${ }^{130}$ In so holding, the district court rejected the authority of cases from several circuits that addressed closely related issues, including a Third Circuit case that recognized that due process rights attached upon administrative transfers to maximum security units (the case did not consider the specific question of periodic hearings in long-term custody situations). ${ }^{131}$ The court also distinguished an Eighth Circuit case that held that prisoners in protective custody should have their status "reviewed periodically in a meaningful way"132 on the basis that it had not specified that such status reviews must meet the requirements of Wolff v. McDonnell. Finally, the court asserted that "recent district court cases in other districts," even if directly on point, could not "be said to create clearly established constitutional rights which would strip defendants of their qualified immunity."13s The court further stated that, even if these cases had established such rights, a court could not reasonably expect the defendants to know of them.

Thus, although there was a significant body of law at all three federal judicial levels establishing that due process rights attached to the administrative transfer of prison inmates to maximum security units, the Calloway court did not find such cases sufficient to hold the defendants responsible for according similar rights to prisoners who had already been transferred to such units and who were seeking transfers within the unit. The court apparently required cases exactly, or nearly exactly, on point. ${ }^{134}$

\footnotetext{
129 Id.

130 See id.

131 See id.

232 Id.

133 Id.
}

136 The court found that the law was not clearly established despite the fact that Wolff v. McDonnell, the initial Supreme Court case from which "[t]he law in this area has been evolving" to expand and define "the rights of inmates to due process hearings," was decided in 1974, before the plaintiff"s incarceration in the maximum security unit. See id.

Furthermore, in Wright v. Enomoto, 462 F. Supp. 397 (N.D. Cal. 1976), affd mem., 434 U.S. 1052 (1978), the Supreme Court held that this liberty interest was also implicated when inmates were transferred to maximum security units for administrative reasons, including protective custcdy purposes such as those in Calloway. These requirements were also embodied in the New Jersey standard in effect in 1975, the year when plaintiffs were placed in administrative segregation. Calloway, 544 F. Supp. 
Calloway requires, for a finding of official liability, an unrealistically high and generally unattainable degree of certainty in the applicable law. ${ }^{135}$ The incapacity of the law to reach this degree of certainty may well lead courts that follow this first approach to grant immunity in virtually all cases. While such an approach serves the policy of protecting public officials from frivolous suits, it cannot serve the equally important policy, also emphasized in Harlow, ${ }^{136}$ of holding officials liable for egregious violations of clearly established law. On the contrary it might lead public officials to believe they may have "one bite" of the apple for any particular constitutional violation. ${ }^{137}$

If courts consistently require that the cases establishing the applicable law bear a strict factual correspondence to the cases under consideration, individual section 1983 claims arising in slightly varying factual contexts may be completely foreclosed, as the Calloway result itself amply demonstrates. More generally, Calloway's approach thwarts the development of potential causes of action that might otherwise emerge from individual cases, were they to survive the qualified immunity defense. Thus the usefulness of section 1983 as a tool to develop and expand the realm of civil rights may be significantly limited. To the extent that courts employ this strict approach, protection and development of civil rights via section 1983 will most likely stagnate. ${ }^{138}$

at 607 .

${ }^{135}$ Cf. Wood v. Strickland, 420 U.S. 308, 329 (1975) (Powell, J., dissenting) (rejecting majority notion of "settled indisputable law" and "unquestioned constitutional rights").

${ }^{138}$ Harlow noted that "[i]n situations of abuse of office, an action for damages may offer the only realistic avenue for vindication of constitutional rights." Harlow, 457 U.S. at 814 (citing Butz v. Economou, 438 U.S. 478 (1978); Bivens v. Six Unknown Fed. Narcotics Agents, 403 U.S. 388 (1971)).

187 See, e.g., Hixon v. Durbin, 560 F. Supp. 654, 665 (E.D. Pa. 1983) (Court found that defendants, Acting Attorney-General and General Counsel of Pennsylvania, had violated plaintiff's due process rights by denying him a renewed employment contract. Nevertheless, the court felt compelled by Harlow to uphold defendants' claims of qualified immunity, noting that the Supreme Court might well have "intended to establish a 'one bite' rule for government officials, so that they will be protected from liability for damages until another official has been held to have violated the Constitution in a case involving identical factual circumstances.").

138 This result may well be what Justice Powell intended to achieve through Harlow's modification of the qualified immunity test, given his concern that the creation of rights "inviting redress in the courts generat[ed] an ever-widening stream of litigation" and thus increased the federal caseload. See Powell, Orison S. Marden Memorial Lecture, supra note 74, at 459 (footnote omitted); see also Maine v. Thiboutot, 448 U.S. 1, 20-26 (1980) (Powell, J., dissenting).

The weakening of section 1983 and its counterpart, the Bivens-type damages action against federal officials, is a development that some judges will welcome and encourage. One court, for instance, praised Harlow's "efforts to cram the Bivens genie back into the bottle" and noted that

[Harlow] may be read as intending to encourage the district courts, in 


\section{B. The Second Approach: Application of General Legal Principles}

The second approach that the lower courts have used is less rigid than the first. It requires defendants to know and apply general legal principles in appropriate factual situations. Defendants are not required to "predic[t] the future course of constitutional law"139 but must consider the possible relevance of law established in analogous factual situations. ${ }^{140}$

An example of this approach is found in Anderson v. Central Point School District No. $6 .{ }^{141}$ In Anderson a schoolteacher/athletic coach sent his proposals for changing the district's athletic policies and programs directly to the School Board, rather than sending them first to his immediate supervisor as required by the district's "channels rules." The superintendent removed him from his coaching duties for violating the channels rules. The teacher thereupon sued the superintendent individually and the school board under section 1983, claiming that he had been removed from his coaching duties for exercising his first amendment rights. The defendant superintendent raised the defense of

Bivens litigation, to grant summary judgment in favor of harried federal. officials on the issue of "good faith," in advance of trial, and indeed before a non-frivolous plaintiff has had a chance to avail himself of the usual hectoring, expensive and dilatory pre-trial depositions of which the federal judiciary appears to be so fond.

Dale v. Bartels, 552 F. Supp. 1253, 1263 (S.D.N.Y. 1982). The court was pessimistic, however; in advocating absolute immunity, it noted, "[t]he Harlow decision seems to us a small court-plaster which cannot stanch the hemorrhage of governmental efforts and resources expended in avoiding or resisting the ever increasing spiteful and unfounded torrent of Bivens claims." Id. at 1266 n.1.

While the Dale $v$. Bartels language is more vehement than that in most discussions of section 1983 and Bivens actions, the court's wish to reduce such litigation may be a relatively common attitude within the federal judiciary. But see Eisenberg, supra note 8 , at 482,484 (discussing and disagreeing with "false impressions about the nature and burden of section 1983 litigation").

189 Pierson v. Ray, 386 U.S. 547, 557 (1967).

140 See, e.g., Williams v. Bennett, 689 F.2d 1370, 1381-82 (11th Cir. 1982) (legal principles set forth in previous case, that certain Alabama prison conditions constitute cruel and unusual punishment, apply to plaintiff's situation and preclude defendants' immunity), cert. denied, 104 S. Ct. 335 (1983); Lowe v. Carter, 554 F. Supp. 831 (E.D. Mich. 1982) (denying defense of immunity where prison officials ignored plaintiff's attempts to challenge confinement in administrative segregation despite Department of Corrections rule mandating monthly review of a prisoner's administrative segregation status); Benford v. American Broadcasting Cos., 554 F. Supp. 145 (D. Md. 1982) (fourth amendment standards of privacy set forth in Katz apply to filming of insurance salesman presenting cancer insurance to members of investigatory congressional team posing as prospective purchasers); Nakao v. Rushen, 545 F. Supp. 1091, 1092-93 (N.D. Cal. 1982) (case law holding in-prison warrantless search permissible only forr "justifiable purpose[s] of imprisonment or prison security" bars defendant's assertion of good faith defense in case where jury could reasonably conclude that search in issue served none of the permitted purposes).

141554 F. Supp. 600 (D. Or. 1982). 
immunity, asserting that the plaintiff had been disciplined, not in retaliation for any exercise of constitutional rights, but rather because he had violated the district's administrative rules. ${ }^{142}$ If those rules violated "clearly established" first amendment rights, the defendant argued, he had had no way of so knowing.

Both parties in Anderson referred to Pickering v. Board of Education $^{143}$ for an enumeration of the factors to be balanced to determine whether a teacher's communications to a school board constituted protected speech. The superintendent argued that Pickering did not clearly establish whether the channels rules were impermissible, that there was therefore no "clearly established" law against disciplining teachers for violations of those rules, and that as a public official he was accordingly entitled to claim qualified good faith immunity. ${ }^{\mathbf{1 4 4}}$

The trial court disagreed with the defendant's characterization of Pickering. It began by observing that the Supreme Court had held, since Pickering, "that any law which imposes a prior restraint on the exercise of first amendment rights comes to the court 'with a heavy presumption against its constitutional validity." "145 The court viewed the channels rules as such a prior restraint; this characterization was based upon Rosen $v$. Port of Portland, ${ }^{146}$ a Ninth Circuit case, which held that advance notice requirements that condition the exercise of free speech rights are unconstitutional. ${ }^{147}$ Although Rosen had been decided two days after the superintendent had dismissed the plaintiff from his coaching job, the Anderson court felt that the case demonstrated that " 'the constitutional standard was clearly established" " because Rosen itself drew upon previous cases that clearly indicated that the channels rules constituted a violation of first amendment rights. ${ }^{148}$

The Anderson court thus held the defendant responsible both for

112 Id. at $603-04,608$.

143391 U.S. 563, $569-73$ (1968). Pickering established "guidelines for determining whether a plaintiff's conduct is protected activity." Anderson, 554 F. Supp. at 606. The guidelines require that a citizen's interest in commenting upon matters of public concern be "balanced" with the interests of the school district in "providing efficient public service." Id. Further, because the school system is a general public concern, persons within the system "have the right to publicly address the pertinent issues 'without fear of retaliatory dismissal." "Id. (quoting Pickering, 391 U.S. at 571-72).

144 Anderson, 554 F. Supp. at 607-08.

${ }^{345}$ Id. at 608 (quoting Vance v. Universal Amusement Co., 445 U.S. 308, 317 (1980); Bantam Books v. Sullivan, 372 U.S. 58, 70 (1963)).

148 641 F.2d 1243 (9th Cir. 1981) (discussing the constitutionality of requirement that groups desiring to exercise first amendment rights at airport terminal register in advance).

147 Id. at 1247.

148 Anderson, 554 F. Supp. at 608 (quoting Fujiwara v. Clark, 477 F. Supp. 822, 833 n.32 (D. Hawaii 1979), rev'd on other grounds, 703 F.2d 357 (9th Cir. 1983)). 
knowing the principles applicable to a teacher's right to communicate directly with a school board and for applying those principles to a particular factual context. For the superintendent to fulfill his responsibility, then, he would have to recognize that the channels rules constituted an impermissible prior restraint on speech and to understand that the law required administrative rules restricting speech "bear a 'substantial relation' to a 'weighty governmental interest,' . . . [and] be drawn with narrow specificity."148

This second approach mirrors the analysis of the Harlow concurrence. It assumes that the law that governs a particular defendant's actions, even if that law is ambiguous, nevertheless includes certain knowable principles, and it assumes that a defendant can be held responsible for applying these principles to a given factual context. ${ }^{160}$ The approach also allows for differences among defendants regarding their actual knowledge of applicable law. Thus, while a purely objective analysis of case law might reveal some ambiguity in the law that could excuse a "reasonable" public official from liability, the second approach also allows a court to hold particular defendants accountable for specialized legal knowledge that they actually possessed on the basis of an "objective" canvass of the applicable law. ${ }^{151}$

While the first approach to Harlow's qualified immunity test, exemplified by Calloway, advances the policy of protecting public officials, it is so rigid that it threatens the viability of the section 1983 action as a means of protecting civil rights. ${ }^{162}$ The second approach, however, provides a reasonable accomodation of the opposing policies. Courts may strictly adhere to the Harlow mandate to protect public officials by finding that the applicable law, even when broadly construed, was simply too ambiguous for a court to hold a reasonable official responsible for applying it in a particular factual context. A court retains the discretion, given the wide range of law that can be characterized as ambiguous, to cut off insubstantial or frivolous claims at the earliest stage of the litigation. Yet, the approach is flexible enough to enable courts to hold public officials responsible not only for applying

140 Anderson, 554 F. Supp. at 608 (quoting Rosen, 641 F.2d at 1246).

180 See Freed, supra note 65, at 526, 558-59.

${ }^{161}$ Cf. Harlow, 457 U.S. at 820-21 (Brennan, J., concurring). The Harlow concurrence interpreted the majority opinion as allowing, in certain cases, a factual inquiry into a defendant's subjective state of mind. Such an inquiry would entail extensive discovery, which the majority resolutely attempted to preclude. Nevertheless, Justice Brennan noted, the majority standard could not be interpreted to "allow the official who actually knows that he was violating the law to escape liability for his actions." Id. at 821.

182 See supra text accompanying notes 135-38. 
"clearly established" law in situations that closely resemble the factual context of relevant precedent, but also for knowing general legal principles and applying them in circumstances similar to those described in established case law. This approach requires a public official to exercise legal judgment before she acts, but such a demand is surely not unreasonable given the self-evident desirability of having public officials carefully consider the legal implications of their actions. ${ }^{183}$

This more flexible approach aids courts that strive to minimize litigation pressure on defendant-officials; it halts insubstantial section 1983 suits at the pre-discovery stage, in accordance with the Harlow mandate. At the same time, the approach allows courts to preserve the section 1983 cause of action as a vehicle for protecting and expanding federal constitutional rights.

\section{G. The Third Approach: Anticipation of Legal Developments}

The third approach that has been taken by lower federal courts requires that defendants anticipate and act in accordance with discernable trends in the law. An example of a court employing this approach is provided by Forsyth $v$. Kleindienst. ${ }^{154}$ Forsyth involved claims arising out of the interception, by a warrantless wiretap, of the plaintiff's telephone conversations with a third party. ${ }^{155}$ The defendants, former United States Attorney General John Mitchell and two FBI agents, moved for summary judgment on the basis of the immunity defense. ${ }^{158}$ After considering the applicable case law at the time that Mitchell had approved the wiretaps, the district court decided that Mitchell was not entitled to qualified immunity and denied summary judgement. ${ }^{\mathbf{1 8 z}}$

The court found ${ }^{\mathbf{1 5 8}}$ that the plaintiff's rights had been clearly es-

163 See Harlow, 457 U.S. at 819 ("Where an official could be expected to know that certain conduct would violate statutory or constitutional rights, he should be made to hesitate ...."). Holding officials responsible for knowing the law and for acting upon their knowledge does not necessarily lead to increased litigation; it may, in fact, lead to a reduction because of increased compliance with the law.

184551 F. Supp. 1247 (E.D. Pa. 1982).

165 The third party, Professor William Davidon, was the target of the tap. Electronic surveillance of Davidon's telephone conversations was maintained from December 1970 through January 1971. Three conversations involving Forsyth were intercepted and recorded by government agents in December 1970 . Id. at 1249 .

${ }_{158} I d$. at 1249-50. Mitchell claimed absolute immunity, a claim the court denied because it determined that his actions were not "so closely connected or essential to a criminal prosecution to bring him within the 'quasi-judicial immunity' discussed in Imbler [v. Pachtman, 424 U.S. 409, 420 (1976)] and Butz [v. Economou, 438 U.S. 478, 509-17 (1978)]." Forsyth, 551 F. Supp. of 1251. The court went on to consider Mitchell's eligibility for qualified immunity. Id. at 1253-61.

${ }_{167}^{10}$ Id.

158 Id. at 1255-59. 
tablished by Katz $v$. United States, ${ }^{159}$ as subsequently explicated by United States v. United States District Court ["Keith"],180 and by Title III of the Omnibus Crime Control and Safe Streets Act of $1968,{ }^{181}$ the applicable statute governing wiretapping. Although Keith was decided by the Supreme Court two years after the wiretap at issue in Forsyth was installed, the Forsyth court noted that Keith represented "no break with the past but rather [was] a logical application of the existing law."162 Thus, the court found, the principles enunciated in Keith had been previously established and were knowable at the time that Forsyth's conversations were intercepted. ${ }^{163}$

Mitchell argued that the law governing his actions was not "clearly established" because some sections of Title III "countermanded" its "overall proscription of warrantless wiretapping."164 The court did not find this argument persuasive. In its view any ambiguities in Title III increased, rather than foreclosed, Mitchell's responsibility to act cautiously. "At the very least," the court stated, Mitchell should have "entertained serious doubts" about his reading of the statute and thus about the legality of the wiretap. ${ }^{165}$

Forsyth ostensibly based its analysis of the defendant's qualified immunity claim on the Harlow test. The court extensively cited Justice Powell's majority opinion, which it acknowledged "enunciate[d] a test for the qualified immunity of government officials that may be viewed as more favorable to the defendant."168 Yet, its analysis, based upon a view that a defendant must foresee whether the illegality of her action was foreshadowed by existing law and upon a conception that statutory ambiguities enhance susceptibility to liability; yields a result contrary to the one Powell intended. ${ }^{167}$

159389 U.S. 347 (1967) (holding warrant required where there is reasonable expectation of privacy).

160407 U.S. 297 (1972) (holding electronic surveillance conducted for national security purposes subject to fourth amendment warrant requirements where the government seeks to institute surveillance of a United States citizen).

161 U.S.C. $\$ \S 2510-2520$ (1982) (proscribing warrantless wiretaps, effective June 19, 1968).

162 Forsyth, 551 F. Supp. at 1255.

${ }^{163}$ Keith's consistency with previously established law was underscored by the fact that, in Zweibon v. Mitchell, 606 F.2d 1172 (D.C. Cir. 1979), cert. denied, 453 U.S. 912 (1981), the D.C. Circuit applied Keith retroactively. The court noted, "We believe that [Keith and earlier cases] . . . did not announce a new principle of law, but simply applied the constitutional warrant requirement to national security situations. As a result, we cannot say that the outcome in those cases was not clearly foreshadowed." Zweibon, 606 F.2d at 1179.

104 Forsyth, 551 F. Supp. at 1258.

180 Id.

168 Id. at 1253.

167 See supra text accompanying notes 86-92. 
Because the defendant, Mitchell, was in a unique position "reasonably to know the law," Forsyth may represent an approach applicable only to defendants in comparable positions. ${ }^{168}$ Mitchell's unique knowledge of the current state of applicable law, in fact, figured importantly in the court's decision. ${ }^{\mathbf{1 6 9}}$

If the approach were more generally applied, however, it would create an extremely strict standard favoring section 1983 plaintiffs but would do so at the expense of creating an intolerable disincentive to vigorous decisionmaking by burdening public officials with a duty to anticipate developments in constitutional law. ${ }^{\mathbf{1 7 0}}$

Rather than carving out a third approach to post-Harlow qualified immunity analysis, cases like Forsyth should therefore be viewed as an application of the second approach described above. Thus Mitchell may be seen as exemplifying the defendant who had actual knowledge of the law and who was therefore particularly able to know and apply general legal principles to specific factual situations. In this view Mitchell, like any other public official, can be held responsible for knowing, applying, and following the law pertinent to his position. ${ }^{171}$

\section{Conclusion}

The primary aim of immunity doctrine is to permit public officials to carry out their tasks without the hesitation caused by fear of potential liability. Protection of the public official is regarded as furthering

168 That result conflicts with the qualified immunity policy of affording particular protection to officials in relatively sensitive, discretionary, and higher-ranking positions. See Harlow, 457 U.S. at 807; Scheur v. Rhodes, 416 U.S. 232, 247 (1974); see also Schuck, supra note 6 , at 321 . It does, however, coincide with concerns that officials in such positions are especially able to abuse their positions. See supra text accompanying notes $76-77$.

169 As the court noted, Mitchell's official capacity entailed a duty to know the law. Forsyth, 551 F. Supp. at 1258. Given this duty, the court characterized Mitchell's actions as a "gamble" that Justice White's concurring opinion in Katz, which advocated warrantless searches for national security purposes, would ultimately prevail. Id. at 1256 (citing Katz, 389 U.S. at 363 (White, J., concurring)). The likelihood that the gamble would fail, however, should have been apparent to the Justice Department at the very time of the Forsyth wiretap in light of developments leading up to the district court's decision in Keith. That decision was based upon a determination of whether electronic surveillance evidence was unconstitutionally tainted. The motion initiating the decision "was filed . . . more than one month prior to the Attorney General's authorization of the wiretap at issue" in Forsyth. 551 F. Supp. at 1255; cf. Hixon v. Durbin, 560 F. Supp. 654 (E.D. Pa. 1983) (holding Acting Attorney General and General Counsel of Pennsylvania entitled to qualified immunity for not renewing an employment contract because state statute authorizing the position in question had never before been construed by state courts).

170 See supra notes 68-73 and accompanying text.

171 See supra text accompanying notes 150-51. 
the public good by facilitating efficient and effective government through unhampered decisionmaking. This policy, however, can conflict with the need to restrain public officials from abusing their positions in violation of the law. The theoretical point of accomodation between these conflicting needs is qualified immunity.

Qualified immunity is designed to balance the competing policies by looking to the good faith of the official whose actions are in question. The content of this good faith determines the balance reached between the competing values furthered by immunity on the one hand or liability under section 1983 on the other.

As this Comment has noted, the Supreme Court has long struggled to define the standard by which lower courts should test an official's good faith so as to ensure the appropriate balance between the competing policies. The Court intended, in Harlow $v$. Fitzgerald, ${ }^{\mathbf{1 7 2}}$ to correct the perceived imbalance in favor of plaintiffs that a majority of the Court believed had resulted from previous qualified immunity analysis. As demonstrated by an examination of the ways in which lower courts may interpret Harlow, however, the case has the potential, if misconstrued, to effect a new, and equally objectionable, imbalance in favor of defendants and thereby to constrict the significance of section 1983. Improper constructions of Harlow might cause section 1983 to be vitiated as a force for deterring official wrongdoing, to be diminished as a vehicle for compensating victims, or to be contracted as a mechanism for extending federal constitutional rights.

Loss of section 1983's deterrent effect may result because use of a narrowly construed "objective" standard presents the possibility that public officials will engage in unpunished abuse of office by operating in gray areas of the law. ${ }^{173}$ Loss of section 1983's reparational effect may result because use of the objective standard can be highly favorable to defendants if courts regularly require a strict factual correspondence between cases establishing law and the cases under consideration. This creates the risk that potentially substantial suits may be sifted out along with frivolous ones, a threat exacerbated by Harlow's mandate that the objective inquiry precede discovery. Finally, the loss of section 1983's development potential may result because use of an unduly restrictive objective standard can stultify the exploration of new causes of action under the section.

This Comment has advocated that the lower courts adopt a flexi-

172457 U.S. 800 (1982).

173 Thus, in Forsyth v. Kleindienst, 551 F. Supp. 1247 (E.D. Pa. 1983), the court condemned defendant Mitchell precisely because he had attempted to gamble on the future development of the law. See supra note 169 and accompanying text. 
ble approach to the interpretation of Harlow; only such an approach yields the appropriate accomodation between the competing policies. An objective determination of applicable law should encompass general principles of law which an objectively reasonable official may be held responsible for knowing and applying. While this approach follows the Harlow concurrence in requiring that a defendant's good faith be measured within the factual context of particular cases, it nevertheless eschews the suggestion of the concurring Justices that a subjective inquiry into an official's actual knowledge may be necessary. The second approach thus remains faithful to the mandate of the Harlow majority that good faith be measured on a purely objective standard, without sacrificing the policies embodied in the right of action provided by section 1983. 





The editors of the University of Pennsylvania Law Review are delighted to dedicate this issue to John O. Honnold, the William A. Schnader Professor of Commercial Law. Professor Honnold has served as a teacher and scholar at the University of Pennsylvania for almost forty years. The tributes that follow attest to his warm, generous spirit and the broad scope of his interests, expertise, and influence, particularly in the unification of international commercial law. The Law Review wishes Professor Honnold well as he continues his work both at the Law School and beyond. 